\title{
Konferencja „Miasto w perspektywie onomastyki i historii”
}

5-7 stycznia 2009 roku odbyła się w Poznaniu konferencja naukowa zatytułowana „Miasto w perspektywie onomastyki i historii”, zorganizowana przez Pracownię Onomastyczną Zakładu Gramatyki Współczesnego Języka Polskiego i Onomastyki Instytutu Filologii Polskiej UAM oraz Wydział Filologiczno-Filozoficzny i Komisję Językoznawczą Poznańskiego Towarzystwa Przyjaciół Nauk, przy współudziale Archiwum Państwowego i Archiwum Archidiecezjalnego w Poznaniu. Konferencję otworzyli dziekan Wydziału Filologii Polskiej i Klasycznej prof. dr hab. Tomasz Pokrzywniak i prezes Poznańskiego Towarzystwa Przyjaciół Nauk prof. dr hab. Jacek Wiesiołowski.

Stanowiła ona zwieńczenie prowadzonych pod kierunkiem Ireny Sarnowskiej-Giefing prac nad antroponomastykonem Poznania doby średniopolskiej ${ }^{1}$, wpisujących się w wieloletnią tradycję badań z zakresu onomastyki (antroponomastyki i toponomastyki) prowadzonych w ośrodku poznańskim. Osiągnięcia onomastów poznańskich zaprezentował - w wykładzie otwierającym obrady - Karol Zierhoffer (Dorobek i perspektywy poznańskiej onomastyki).

Intencją organizatorów konferencji było zintegrowanie przedstawicieli różnych dyscyplin humanistycznych podejmujących w swych badaniach zagadnienia związane z przestrzenią miejską. W wyznaczonym zakresie tematycznym znalazły się takie zagadnienia, jak: kształtowanie się nazwiska mieszczańskiego w Polsce i Europie; antroponomastykony wybranych miast; dynamika przemian nazewniczych związanych z dziejami miasta, regionu, kraju; nazewnictwo miejskie; doświadczenie historyczne jako niezbędny kontekst dla badań onimii miejskiej oraz miasto z perspektywy dokumentów archiwalnych (ewaluacja źródeł pod kątem badań nad onimią).

\footnotetext{
${ }^{1}$ Ministerialny projekt badawczy nr 1 H01 D 04230.
} 
Proponowana tematyka spotkała się z dużym zainteresowaniem przedstawicieli krajowych i zagranicznych środowisk naukowych. Oprócz gości reprezentujących główne ośrodki akademickie w Polsce, swój akces zgłosili językoznawcy z Czech, Słowacji, Niemiec, Rosji i Ukrainy (57 referentów). W toku trzydniowych obrad - plenarnych i w trzech sekcjach - zaprezentowano 40 referatów ujmujących z różnych perspektyw (onomastyki, historii, archiwistyki) problematykę miasta i jego mieszkańców. Obrady odbywały się w Collegium Minus i Collegium Maius UAM oraz w sali obrad Poznańskiego Towarzystwa Przyjaciół Nauk. Integralny element konferencji stanowiły warsztaty i prezentacje prowadzone przez pracowników obu poznańskich archiwów: Archiwum Archidiecezjalnego oraz Archiwum Państwowego.

Wszystkie prezentowane podczas konferencji referaty charakteryzowały się wysokim poziomem merytorycznym - omawiane w nich zagadnienia wymagały podjęcia przez autorów także kwestii teoretycznych (metodologii badań onomastycznych). Najliczniej reprezentowane pole tematyczne (14 wystąpień, w tym 10 plenarnych) objęło zagadnienia związane z antroponomastykonami miast polskich i obcych, obserwowanymi zarówno historycznie, jak i na płaszczyźnie synchronicznej. Rolę rozwijających się od XII wieku miast, a zwłaszcza dużych centrów urbanistycznych, w kształtowaniu się nazwisk niemieckich przedstawił w swoim wystapieniu Fridhelm Debus (Die Bedeutung der Stadt für die Entstehung der deutschen Familiennamen). Pytanie o czynniki kulturowe determinujące przemiany nazewnictwa osobowego w jednym z najbogatszych miast XVII-wiecznej Rusi postawiła Bożena Hrynkiewicz-Adamskich (Siedemnastowieczny antroponomastykon Wielkiego Ustiuga). Nazwom osobowym wyzyskanym do nominacji mieszkańców Węgorzewa (zróżnicowaniu semantycznemu, słowotwórczemu i fonetycznemu tych antroponimów) poświęciła swój referat Maria Biolik (Wybrane nazwiska mieszkańców Węorzewa przykładem kształtowania się nazwisk mieszczańskich na terenie bytych Prus Wschodnich), natomiast antroponimia kresowa na przykładzie imion i nazwisk historycznych mieszkańców Jazłowca i Drohobycza, ze szczególnym uwzględnieniem hybryd językowych pojawiających się tu na skutek wielowiekowego sąsiedztwa z osadnictwem wschodniosłowiańskim, omówiona została w referacie Wandy Szulowskiej (Z antroponimii kresowej końca XIX wieku). Wnioski o charakterze onomastycznym, kulturowym i osadniczo-etnicznym, będące wynikiem analizy nazw osób piastujących władzę w Koszalinie w okresie średniowiecza - określanych bez względu na charakter piastowanego urzędu, burmistrzami - zaprezentował Andrzej Chludziński (Nazwy osobowe burmistrzów Koszalina (do 1500 roku)). Historycznej antroponimii Hrubieszowa dotyczył referat Marcina Kojdera, prezentujący sposoby nominacji osób (mężczyzn i kobiet) utrwalone w świeckich i ko- 
ścielnych księgach sądowych (Uwagi o nazewnictwie osobowym mieszkańców Hrubieszowa w XVII i XVIII wieku). Nazewnictwo osobowe Unierzyża na Mazowszu, na podstawie sumariusza miejscowej parafii dokumentującego imiona i nazwiska parafian w latach 1670-1800, stanowiło przedmiot referatu Małgorzaty Pawikowskiej (Antroponimia Unierzyża na Mazowszu z poczatku $X V I I$ wieku). Próbę zweryfikowania istniejącego w onomastyce poglądu, iż nazwiska zakończone na -owicz // -ewicz są historycznie nazwiskami mieszczańskimi, podjęła Małgorzata Magda-Czekaj (Nazwiska na -owicz z wybranych miast Polski od XVI-XVIII wieku). Ostatni z przywołanych referatów koresponduje tematycznie $\mathrm{z}$ teoretycznymi ustaleniami zawartymi w plenarnym referacie Ewy Wolnicz-Pawłowskiej (Czy istnieje polskie nazwisko mieszczańskie?), która - na podstawie analizy obszernej literatury przedmiotu - dowodzi braku modelowej formacji sufiksalnej, dającej się przypisać środowisku mieszczańskiemu.

Specyfiką antroponomastykonu licznych miast polskich jest wzajemne przenikanie się nazewnictwa rodzimego i obcego - problematyce tej poświęcone zostały dwa referaty. Małgorzata Jaracz omówiła imiona i nazwiska przedstawicieli mniejszości żydowskiej zamieszkującej Bydgoszcz w latach 1920-1939 (Antroponimia Żydów w przestrzeni nazewniczej międzywojennej Bydgoszczy), natomiast w wystapieniu Moniki Kresy zagadnienie to ujęto komparatystycznie i kontrastywnie (Analiza porównawcza dziewiętnastowiecznych nazwisk katolików i Żydów (mieszkańców Węrowa) jako dowód wzajemnych interferencji, różnic i podobieństw dwóch systemów antroponimicznych, ksztaltujacych się w jednym środowisku miejskim).

Trzy referaty prezentowały wyniki badań nad historyczną antroponimią mieszkańców Poznania prowadzonych przez zespół Pracowni Onomastycznej UAM. Widziane z perspektywy różnych typów dokumentów zagadnienia dotyczą kształtowania się i stabilizacji nazwisk mieszkańców - członków jedynej zlokalizowanej w murach miasta parafii (Aleksandra Kulupa, Nazwiska poznaniaków na podstawie ksiag metrykalnych parafii św. Marii Magdaleny $w$ Poznaniu) oraz nazwisk obywateli miasta - cives (Kinga Banderowicz, Poznaniacy - mieszkańcy Wielkopolski, krajanie czy obywatele świata? Procesy imigracyjne uchwycone w nazwiskach i tekście poznańskich ksiag przyjęć do prawa miejskiego (1575-1793)). Podsumowanie dotychczasowych badań nad nazwiskami mieszkańców Poznania doby średniopolskiej z perspektywy prac związanych $\mathrm{z}$ ich opublikowaniem $\mathrm{w}$ formie słownika onomastycznego zaprezentowane zostało w plenarnym wystapieniu Ireny Sarnowskiej-Giefing (Stownik nazwisk mieszkańców Poznania XVI-XVIII wieku i jego cele: onomastyczny, ogólnojęzykowy $i$ historyczno-kulturowy). Wyznaczony cel onomastyczny wiąże się $\mathrm{z}$ odtworzeniem procesu kształtowania się i stabilizacji nazwiska 
(charakterystyczne dla Poznania jest załamanie się w połowie XVII wieku w związku z najazdem szwedzkim - zarysowującej się w XVI wieku wyraźnej tendencji stabilizacyjnej). Z celem ogólnojęzykowym (rozumianym jako dopełnienie w opisie zjawisk językowych, uściślenie ich chronologii i geografii) pozostają styczne rozpoznania dotyczące odbitych w poznańskim nazewnictwie osobowym średniopolskich i regionalnych (wielkopolskich) cech językowych. Badaniom nazewnictwa osobowego Poznania - terenu ścierania się dwóch języków (polskiego i niemieckiego) oraz dwóch kultur - wyznaczono także cel historyczno-kulturowy. W referacie wskazano między innymi na proces $d y f u z j i$, tj. rozprzestrzeniania się zjawisk przynależnych do zachodniej kultury mieszczańskiej (kultury onimicznej niemieckich wspólnot miejskich).

Poza problematykę antroponimii miejskiej wykraczały dwa plenarne wystąpienia referentów poznańskich: Bogdana Walczaka (Najczęstsze nazwiska wielkopolskie) i Jerzego Sierociuka (Bukowiec Górny - dzieje wsi nazwiskami pisane). Autor pierwszego z nich na podstawie Stownika nazwisk wspótcześnie w Polsce użwanych Kazimierza Rymuta zaprezentował nazwiska wykazujące w Wielkopolsce frekwencję wyraźnie wyższą niż w innych regionach kraju. Zwrócił też uwagę na wartość konotacyjną wielkopolskiego nazwiska Kaczmarek. W referacie dialektologa, Jerzego Sierociuka, pokazany został proces kształtowania się nazwisk mieszkańców wielkopolskiej wsi (ciagłość związana z zasiedziałością i rodzimość lokalnej antroponimii).

Drugi krąg tematyczny tworzą referaty poświęcone nazewnictwu miejskiemu (siedem wystapień), szczególnie plateonimii, która stanowiła zasadniczy przedmiot rozważań Aleksandry Cieślikowej (Historia, tradycja i współczesność obecne dzięki antroponimom w nazwach ulic Krakowa), podejmującej nie tylko próbę odpowiedzi na pytania o czas, motywację, formę, wzór, normę i ideologię - czynniki wpływające na wybór i społeczną akceptację antroponimów, patronów ulic w Krakowie, ale też o komunikacyjny obieg plateonimów i rozumienie pojęcia tradycji w tym zakresie. W grupie tej mieszczą się również wystąpienia Elżbiety Borysiak (Polskie miasta-Zdroje w świetle nazw ulic) oraz Jerzego Grzelaka (Nazewnictwo ulic Szczecina w okresie 1945-1990 jako narzędzie formowania nowej, postępowej świadomości społecznej). Kolejne wystapienia poświęcone były bądź analizie onomastykonu konkretnych miast (Iwona Żuraszek-Ryś, Kształtowanie się nazewnictwa miejskiego Zielonej Góry) lub określonej kategorii onimicznej (Elena Palinciuc, Nazwy lokali handlowych na Starym Mieście w Krakowie), bądź zagadnieniom natury lingwistycznej (Jana Marie Tušková, Gramatické tvary českých měst - jejich historie a současnost oraz David Vaculik, Problematyka nazewnictwa miejskiego). Z referatami o charakterze analitycznym bezpośrednio łączą się wystapienia plenarne, których przedmiot stanowiły teoretyczne aspekty urbonimii 
i urbanonimi (cztery referaty): Rudolfa Šrámka (Problematika typologie názvi̊ českých měst), Zygmunta Zagórskiego (Problematyka i metody badań nazewnictwa wspólnoty miejskiej) oraz Mieczysława Balowskiego (Zmiana funkcji petnionych przez nazwy ulic (od funkcji lokalizacyjnej do symbolicznej)).

Kolejną grupę tematyczną stanowily referaty (siedem wystąień) podejmujące szeroki kontekst badań onomastycznych, niejednokrotnie wzbogacony o ustalenia innych dyscyplin humanistycznych, reprezentujące onomastykę kulturową i literacką. Interferencje badań onimicznych oraz historii (w tym historii sztuki) i teologii ukazywały referaty Katarzyny Węgorowskiej (Wilno $w$ perspektywie onomastyki, malarstwa i historii), Beaty Lukarskiej (Religia w literackim obrazie przestrzeni barokowego miasta) oraz Violetty Jaros (Krajobraz sakralny w przestrzeni onimiczno-spotecznej Częstochowy). Najnowsze ustalenia z zakresu semiotyki znalazły odzwierciedlenie w referacie Małgorzaty Rutkiewicz-Hanczewskiej (Ikoniczny wymiar nazewniczej przestrzeni miasta), po narzędzia badawcze kognitywizmu sięgnęła Eliza Grzelakowa (Toponomastyczna kreacja jezzkowego obrazu miasta - czas i przestrzeń). Magdalena Graf zaprezentowała literackie obrazy stolicy Wielkopolski (Poznań: miasto rzeczywiste - miasto literackie), instrumentarium kulturoznawstwa wykorzystała Aleksandra Kosicka-Pajewska w swej charakterystyce miast stolic ( $\mathrm{Po}-$ znań $i$ Warszawa - miasta żywe w XIX wieku).

Interesujące były referaty prezentowane w Archiwum Państwowym, w których perspektywa onomastyczna ściśle wiązała się z zagadnieniami dotyczącymi źródeł archiwalnych stanowiących przedmiot ekscerpcji materiału antroponimicznego (trzy referaty). Maria Czaplicka-Jedlikowska określiła dotychczasowy stopień wyzyskania zasobów archiwalnych do badań nad nazewnictwem Bydgoszczy (Miasto Bydgoszcz z perspektywy dokumentów archiwalnych w zakresie badań onomastycznych), Danuta Lech-Kirstein omówiła specyfikę ksiąg cechowych Opola jako cennego źródła rodzimej antroponimii (Księgi cechowe miasta Opola jako cenne źródto nazw osobowych), o istotnym elemencie badań nad historycznym nazewnictwem, jakim jest grafia poszczególnych dokumentów i jej wpływ na odczytania nazw własnych przez onomastów, traktował referat Marii Trawińskiej (Grafia nazw własnych w XIV-wiecznej poznańskiej księdze ziemskiej). Podjęta w nich problematyka korespondowała z tematami odbywających się w trakcie konferencji warsztatów prowadzonych przez poznańskich archiwistów. Niezbędny kontekst dla referatów językoznawczych (onomastycznych) stwarzały towarzyszące warsztatom wystapienia wybitnych poznańskich historyków poświęcone dziejom miasta oraz jego socjotopografii: Tomasza Jurka (Poznań i jego mieszkańcy w XIII wieku) i Jacka Wiesiołowskiego (Poznań i jego mieszkańcy w XIV-XVIII wieku). Zasadniczym celem warsztatów było jednak udostępnienie i krytyczne omówienie dokumentów 
znajdujących się w zasobach poznańskich archiwów, szczególnie zaś wskazanie ich przydatności do badań onomastycznych. Prowadząca warsztaty w Archiwum Państwowym kustosz Zofia Wojciechowska zaprezentowała akta miasta Poznania z lat 1344-1793, w tym m.in. uznawany za najstarszy dokument kancelarii miejskiej - dekret Rady Miasta; najstarszą księgę radziecką z lat 1398-1449; akta sądów oraz miejską dokumentację rachunkową z XVI wieku. W Archiwum Archidiecezjalnym uczestnicy konferencji mieli okazję obejrzeć przygotowaną wystawę archiwaliów i zapoznać się z nowymi metodami udostępniania ksiag metrykalnych w ramach Cyfrowego Archiwum Archidiecezji Poznańskiej. Kustosz Magdalena Lange omówiła wartość poszczególnych dokumentów archiwalnych dla badań antroponimicznych, uczestnicy wysłuchali też prelekcji na temat archiwaliów dokumentujących działalność centralnych urzędów diecezjalnych oraz organizacji i stowarzyszeń kościelnych.

Trzydniowe obrady podsumował Rudolf Šrámek. Konferencję zamykała wycieczka do Gniezna, podczas której goście mieli okazję zwiedzić katedrę oraz zapoznać się ze skarbami gnieźnieńskiego archiwum.

Wszystkie wygłoszone referaty, także zgłoszone wcześniej (zapowiadane w wydanym przed konferencją zeszycie streszczeń), których autorzy z przyczyn losowych nie mogli wziąć udziału w konferencji, zostaną opublikowane w tomie pokonferencyjnym, wydanym przez Wydawnictwo Poznańskiego Towarzystwa Przyjaciół Nauk.

Konferencja pokazała, jak ważne jest interdyscyplinarne podejście do badań (diachronicznych i synchronicznych), których przedmiot stanowią nazwy własne - wykładniki narodowej kultury. Współpraca uniwersytetu i archiwów pozwoliła dowieść, że stosunek do dorobku kulturalnego wyraża się najpełniej w zintegrowanych działaniach, pozwalających na poznanie go i zachowanie dla następnych pokoleń. 